\title{
Seasonal Variation of Heavy Metal Concentrations in Water and Sediment Samples of Erelu Reservoir and their Effects on its Macro-Invertebrates
}

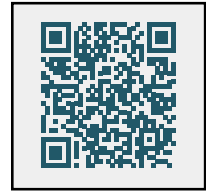

\begin{abstract}
Amusat AI*
Department of Science Laboratory Technology, Oyo State College of Agriculture and Technology, Nigeria
\end{abstract}

*Corresponding author: Amusat AI (Ph. D), Department of Science Laboratory Technology, Oyo State College of Agriculture and Technology, Igboora, Nigeria, Tel: 08034561670; Email: wumiamusat@gmail.com

\section{Research Article \\ Volume 4 Issue 5}

Received Date: June 04, 2020

Published Date: July 21, 2020

DOI: $10.23880 /$ jenr-16000207

\section{Abstract}

Heavy metal is always a concern when introduced in high amount into the body of water particularly the sediment that serves as favourable sinks due to bioaccumulation which indirectly affects the organisms of the aquatic ecosystems. Therefore, this study investigated seasonal variation of heavy metal concentrations of water and sediment samples of Erelu reservoir and their impacts on its macro-invertebrates. Water samples were collected monthly in the morning across the three selected stations between 800am-10am from June 2013-May 2015. Heavy metal concentrations were determined using AAS model Analyst PGP 10. Macro-invertebrates were collected using Van-veen grab of $66.6 \mathrm{~cm}^{3}$ surface area, dip-net and sweep nets of mesh sizes $(500 \mu \mathrm{m}$ and $250 \mu \mathrm{m})$ were used for insects on water surface and on vegetation surrounding the reservoir. Macro-invertebrates collected were sorted, counted and identified with standard aquatic taxonomic keys. Data collected were analysed using paired t-test of significant and Pearson's Correlation Coefficient and paired t-test at $\alpha 0.05$. The results showed that $\mathrm{Fe}(\mathrm{mg} / \mathrm{L}), \mathrm{Zn}(\mathrm{mg} / \mathrm{L})$ and $\mathrm{Cr}(\mathrm{mg} / \mathrm{L})$ in water samples were significant $(p<0.05)$ across seasons and stations while $\mathrm{Pb}$ $(\mathrm{mg} / \mathrm{kg})$ and $\mathrm{Zn}(\mathrm{mg} / \mathrm{kg})$ in sediment samples were significant $(p<0.05)$ between seasons and across stations respectively. Zinc $(\mathrm{mg} / \mathrm{L})$ had strong relationship with Iron $\left(\mathrm{r}=0.894^{* *}\right)$ in water samples while Cadmium $\mathrm{mg} / \mathrm{kg}$ had positive significant $(\mathrm{p}<0.05)$ relationship with Iron $\left(\mathrm{r}=0.837^{* *}\right)$ and Chromium $\mathrm{mg} / \mathrm{kg}\left(\mathrm{r}=0.839^{* *}\right)$ in sediment samples respectively. Lead had positive correlation with Odonata $\left(\mathrm{r}=0.743^{*}\right)$; Zinc related with Unionidea $\left(\mathrm{r}=0.691^{*}\right)$ and Cadmium significantly correlated with Capitellida $\left(\mathrm{r}=0.826^{* *}\right)$ in water samples respectively. Lead had relationship with Hygrophila $\left(\mathrm{r}=0.683^{*}\right.$ ); Iron with Capitellida $\left(\mathrm{r}=0.691^{*}\right)$ and Sorbeoconcha $\left(\mathrm{r}=0.692^{*}\right)$; Zinc with Diptera $\left(\mathrm{r}=0.680^{*}\right)$; Chromium with Pulmonata $\left(\mathrm{r}=0.779^{*}\right)$ and Unionidea $\left(\mathrm{r}=0.878^{*}\right)$ while Cadmium related significantly $(p<0.05)$ related with Capitellida $\left(\mathrm{r}=0.854^{* *}\right)$ in sediment samples respectively. The result indicated that the heavy metals both in sediment and water samples has greater influence on macro-invertebrate abundance.

Keywords: Taxonomic keys; Variation; Odonata; Sorbeoconcha; AAS; Aquatic Ecosystem

\section{Introduction}

Heavy metals are naturally occurring metals which have atomic number greater than 20 and specific gravity greater than $5 \mathrm{~g} / \mathrm{cm}^{3}$. Heavy metal has its own merit or demerit, based on this it is categorized into two: Essential and Non-essential. Essential heavy metals are important for living organisms and may be required in the body in minute quantity. Non-essential 


\section{Journal of Ecology and Natural Resources}

heavy metals have no reasonable biological role in living organisms [1]. The essential metals include Manganese, Iron, Copper, Cobalt and Zinc and also known as trace metals, while the non-essential metals are Cadmium, Lead and Mercury, they are very toxic and are referred to as macronutrients. The trace metal elements are needed in smaller quantity and are important for development and stress resistance and many at times for biosynthesis which are useful for different biomolecules like Carbohydrate, chlorophyll, nucleic acids, growth chemicals and secondary metabolites [2]. However, extreme concentrations of important metals may be harmful to living organisms [3]. Metals get into the freshwater due to breaking down of soils and rocks. Rocks are originated out of volcanic outbreaks and different kinds of human activities for example, mining, metal processing or utilization or substances that consist of metal contaminants [4]. Presence of too much heavy metals in freshwaters causes fall in $\mathrm{pH}$ of water, metal solubility rises and metal particles are easily mobile which is the reason why metal toxicity occurs in most soft waters and locking up of metal in the bottom sediment of water bodies for a considerable period of time, since they are non-biodegradable (i.e. cannot be splitted into less injurious constituents in the ecosystem). Harmful chemicals can be accumulated in the body tissue of organisms, particularly fat tissues, depending on the sensitivity of individual species to the contaminants which can also be influenced by factors like the duration of exposure, sex, age e.t.c. Generally, the metal concentrations in invertebrates are varied according to their body weight. In fish, the embryonic and larval phases are normally the most intolerant to the contaminants. Perhaps, benthic organisms are the most throughly influenced by metal strength in the sediment since the benthos serves as the essential store house for the particulate matters that are wiped down into the water ecosystems [5]. Fish, mussel, snails in an aquatic environment alwas accumulate metals in their tissues, when consumed by man the heavy metal poisoning could be transported to human via food chain. Contamination of human energy exchange with toxic heavy metals pose a threat to human health. Examples include Minimata and Itai-itai diseases both in Japan which were caused by consumption of mercury-contaminated fish and Cadmium- contaminated rice respectively that resulted into symptom like Ataxia, numbness of hands and feets, damage to hearing and speech, softening of bones and kidney failure. Higher concentration of trace metals in aquatic ecosystems, organisms of higher trophic levels due to biomagnifications can pose health risk of these organisms or to their human consumers. In other to protect human health from the harmful effects of toxic heavy metals, the human food chains should be constantly monitored for bioaccumulation and biomagnifications of heavy metals [6]. Therefore, this research was designed to examine the seasonal variation of heavy metals in water and sediment samples of Erelu reservoir and their impacts on its macro-invertebrates.

\section{Materials and Methods}

\section{Description of the Study Area}

The study site for this research work is Erelu reservoir. Erelu reservoir is located in Oyo town. It was built on Aawon River along Oyo /Iseyin road in 1959 and was commissioned in 1961 to provide water for drinking, agricultural, irrigational purposes and fishing activities. Currently, it also provides water for International Institute of Tropical Agriculture (IITA) for their nursery unit in Oyo Town. The impoundment of the dam is $161.07 \mathrm{ha}$, and the catchments area is $243.36 \mathrm{~km}$. Erelu reservoir is approximately $6.4 \mathrm{~km}$ from the core of Oyo town and it supplies potable water to the town. An output of 7.5 million litres is released per day, from a reservoir capacity of $10 \mathrm{~cm}^{3}[7,8]$.

\begin{tabular}{|c|c|}
\hline Stations & Description \\
\hline Inlet & $\begin{array}{r}\text { This is located at Oya tutu, 5km away from the reservoir. It has longitude } 3^{\circ} 54^{\prime} 0.5^{\prime \prime} \mathrm{E} \text { and latitude } \\
7^{\circ} 52^{\prime} 15.3^{\prime \prime} \mathrm{N}, \text { surrounded by agricultural field with sandy substrate. }\end{array}$ \\
\hline Reservoir & $\begin{array}{r}\text { This station has longitude } 3^{\circ} 53^{\prime} 5.8^{\prime \prime} \mathrm{E} \text { and latitude } 7^{\circ} 52^{\prime} 42.8^{\prime \prime} \mathrm{N}, \text { located within the reservoir with muddy } \\
\text { substratum and landing stations for the fishermen. Trees provide shade for the water and evergreen veg- } \\
\text { etations, There is less human activities here. }\end{array}$ \\
\hline Outlet & $\begin{array}{c}\text { This location is where water exit into the river, has longitude } 3^{\circ} 55^{\prime} 6.0^{\prime \prime} \mathrm{E} \text { and latitude } 7^{\circ} 54^{\prime} 5.8^{\prime \prime} \mathrm{N} \text {. This sta- } \\
\text { tion has sandy substrate with leave particles, human activities such as ritual bath, cattle grazing, fish catch } \\
\text { with gammalin20 etc. There is overhead bridge that is motorable to villages near the reservoir }\end{array}$ \\
\hline
\end{tabular}

Table 1: Erelu reservoir.

\section{Water Sample and Sediment Collections}

Water samples were collected from each station very early in the morning (8am-10am) once in a month for the 
period of two years (June 2013-May 2015). Water samples for heavy metal analysis were collected in plastic container (2-litres) from selected stations. The sample water taken were transported to the research laboratory and analysed instantly to guarantee that the water quality parameters were sustained.

\section{Heavy Metals Determination in Water and Sediment Samples}

Lead $(\mathrm{Pb})$, Iron $(\mathrm{Fe})$, Zinc $(\mathrm{Zn})$, Cadmium $(\mathrm{Cd})$ and Chromium (Cr) in water samples were determined using an Atomic Absorption Spectrophotometer, Model Analyst A10 PGP. About 2g of water soil sediment was air-dried, grinded and sieved using $2 \mathrm{~mm}$ diameter sieve while the digestion was determined by heating 1 gram of grinded soil sediment with $20 \mathrm{ml}$ of mixture of $70 \% \mathrm{HCLO}_{4}$ and concentrated $\mathrm{HNO}_{3}$ (2:1) to near dryness and $20 \mathrm{ml}$ of $0.5 \mathrm{M} \mathrm{HNO}_{3}$ were added after cooling, sieved and add up to $50 \mathrm{ml}$ with distilled water. The amount of $\mathrm{Pb}, \mathrm{Cr}, \mathrm{Cd}, \mathrm{Zn}$, and Fe were determined using the above model AAS using the procedure [9].

\section{Macro-Invertebrate and Sediment Collections}

The benthic organisms were collected from the sampling stations using a Van-veen grab with a surface area of $66.6 \mathrm{~cm}^{2}$.
Sediments collected from each station were emptied into a pre labeled polythene bags and the samples for heavy metals determination were taken. The sample collected from each station was sieved with a net of mesh size of $0.5 \mathrm{~mm}$ to remove the excess sediments. Macro-invertebrates collected from the residue were air-dried and preservative with naphthalene for onward transfer to the laboratory for identification. Aquatic insect collections were done using a dip-net of 500 $\mu \mathrm{m}$ mesh size. The net was dipped in water at different stations and swirled for about 2-3 minutes at the surface of water to allowed for the entrance of the aquatic insects and their nymphs and were emptied into pre-labelled plastic bottles according to stations. Adult insects like dragonflies, Damselflies were also gathered from the vegetation around the reservoir using a sweep net of mesh size of $250 \mu \mathrm{m}$. The net was swept over vegetation for 2-3 minutes and were emptied into pre-labelled plastic bottles. Aquatic macroinvertebrates were identified using aquatic taxonomic keys, Phyllis, et al. [10-13] and Needham, et al. [14].

\section{Statistical Analysis}

The results of laboratory analysis of Heavy metal concentrations and data collected for aquatic macroinvertebrates were subjected to paired t-test of significance and Pearson's Correlation coefficient (r).

\section{Results}

\begin{tabular}{|c|c|c|c|c|}
\hline Parameters & Seasons & Inlet & Reservoir & Outlet \\
\hline Lead (mg/l) & Rainy & $0.86 \pm 0.09$ & $0.91 \pm 0.08$ & $0.97 \pm 0.11$ \\
& Dry & $1.02 \pm 0.10$ & $1.17 \pm 0.09$ & $1.18 \pm 0.11$ \\
\hline Iron (mg/l) & Rainy & $0.52 \pm 0.05$ & $0.51 \pm 0.05$ & $0.47 \pm 0.71$ \\
& Dry & $0.68 \pm 0.09$ & $0.69 \pm 0.08$ & $0.73 \pm 0.10$ \\
& & $*$ & $1.11 \pm 0.33$ & $1.21 \pm 0.31$ \\
& Rainy & $1.43 \pm 0.36$ & $0.49 \pm 0.07$ & $0.47 \pm 0.06$ \\
\hline Zinc (mg/l) & Dry & $0.52 \pm 0.06$ & $* .35 \pm 0.07$ & $0.22 \pm 0.04$ \\
& Rainy & $0.28 \pm 0.04$ & $0.23 \pm 0.03$ & $0.19 \pm 0.02$ \\
\hline Chromium (mg/l) & Dry & $0.16 \pm 0.02$ & $*$ & $0.19 \pm 0.02$ \\
\hline & Rainy & $0.20 \pm 0.02$ & $0.25 \pm 0.03$ & $0.29 \pm 0.04$ \\
\hline
\end{tabular}

*Significance at $(\mathrm{p}<0.05)$

Table 2: T-test of significance showing seasonal variation of heavy metals from water samples of Erelu Reservoir. 


\begin{tabular}{|c|c|c|c|c|}
\hline Parameters & Seasons & Inlet & Reservoir & Outlet \\
\hline & Rainy & $17.45 \pm 1.50$ & $14.18 \pm 1.16$ & $13.80 \pm 1.34$ \\
Lead (mg/kg) & Dry & $34.82 \pm=4.66$ & $35.03 \pm 3.52$ & $38.91 \pm 4.16$ \\
$*$ & $*$ & $21.82 \pm 3.77$ & $20.14 \pm 5.36$ \\
& Rainy & $17.24 \pm 3.92$ & $26.72 \pm 4.19$ & $22.04 \pm 4.44$ \\
\hline \multirow{2}{*}{ Iron (mg/kg) } & Dry & $25.35 \pm 4.75$ & $2.01 \pm 0.19$ & $2.29 \pm 0.35$ \\
& Rainy & $2.18 \pm 0.23$ & $6.10 \pm 1.18$ & $8.07 \pm 1.75$ \\
Zinc (mg/kg) & Dry & $8.28 \pm 1.92$ & $10.89 \pm 2.35$ & $12.88 \pm 4.91$ \\
& Rainy & $5.69 \pm 1.37$ & $14.52 \pm 2.82$ & $13.80 \pm 4.27$ \\
\hline \multirow{2}{*}{ Chromium (mg/kg) } & Dry & $16.90 \pm 3.75$ & $3.71 \pm 3.61$ & $4.03 \pm 3.92$ \\
& Rainy & $3.43 \pm 2.69$ & $2.44 \pm 2.12$ & $2.52 \pm 1.50$ \\
\hline
\end{tabular}

*Significance at $(\mathrm{p}<0.05)$.

Table 3: Test of significance showing seasonal variation of heavy metals from sediments samples of Erelu Reservoir.

\begin{tabular}{|l|c|c|c|c|c|c|c|c|c|}
\hline \multicolumn{1}{|c|}{ Parameters } & $\mathbf{1}$ & $\mathbf{2}$ & $\mathbf{3}$ & $\mathbf{4}$ & $\mathbf{5}$ & $\mathbf{6}$ & $\mathbf{7}$ & $\mathbf{8}$ & $\mathbf{9}$ \\
\hline 1.Diptera & 1 & & & & & & & & \\
\hline 2.Coleoptera & -0.222 & 1 & & & & & & & \\
\hline 3.Hemiptera & 0.533 & 0.310 & 1 & & & & & & \\
\hline 4.Odonata & 0.490 & -0.155 & 0.555 & 1 & & & & & \\
\hline 5.Lead (mg/l) & -0.185 & -0.070 & 0.212 & $0.743^{*}$ & 1 & & & & \\
\hline 6.Iron (mg/l) & -0.315 & -0.060 & -0.106 & 0.518 & $0.755^{*}$ & 1 & & & \\
\hline 7.Zinc (mg/l) & -0.389 & 0.089 & -0.383 & 0.239 & 0.480 & $0.894^{* *}$ & 1 & & \\
\hline 8.Chromium (mg/l) & -0.438 & 0.077 & 0.083 & 0.489 & $0.837^{* *}$ & $0.833^{* *}$ & 0.635 & 1 & \\
\hline 9.Cadmium (mg/l) & -0.335 & 0.141 & -0.326 & 0.346 & 0.588 & $0.854^{* *}$ & $0.951^{* *}$ & 0.594 & 1 \\
\hline
\end{tabular}

*. Correlation is significant at the 0.05 level (2-tailed).

**. Correlation is significant at the 0.01 level (2-tailed).

Table 4: Pearson's correlation coefficient $(r)$ between water heavy metals parameters with insect macro-invertebrates abundance of Erelu Reservoir.

\begin{tabular}{|l|c|c|c|c|c|c|c|c|c|c|c|c|}
\hline \multicolumn{1}{|c|}{ Parameters } & $\mathbf{1}$ & $\mathbf{2}$ & $\mathbf{3}$ & $\mathbf{4}$ & $\mathbf{5}$ & $\mathbf{6}$ & $\mathbf{7}$ & $\mathbf{8}$ & $\mathbf{9}$ & $\mathbf{1 0}$ & $\mathbf{1 1}$ & $\mathbf{1 2}$ \\
\hline 1. Architaenioglossa & 1 & & & & & & & & & & & \\
\hline 2. Capitellida & 0.056 & 1 & & & & & & & & & \\
\hline 3. Diptera & 0.083 & -0.295 & 1 & & & & & & & & & \\
\hline 4. Hygrophila & 0.637 & -0.132 & 0.005 & 1 & & & & & & & & \\
\hline 5. Pulmonata & 0.211 & -0.134 & 0.322 & 0.045 & 1 & & & & & & & \\
\hline 6. Sorbeoconcha & 0.324 & 0.590 & 0.283 & 0.050 & 0.315 & 1 & & & & & & \\
\hline 7. Unionidea & 0.191 & 0.244 & 0.464 & -0.272 & $0.808^{* *}$ & 0.588 & 1 & & & & & \\
\hline 8. Lead (mg/l) & -0.268 & 0.488 & -0.223 & -0.230 & -0.208 & -0.196 & -0.066 & 1 & & & & \\
\hline 9. Iron (mg/l) & -0.145 & 0.494 & -0.103 & -0.380 & 0.410 & 0.086 & 0.538 & $0.755^{*}$ & 1 & & & \\
\hline 10 Zinc (mg/l) & -0.126 & 0.633 & -0.173 & -0.441 & 0.494 & 0.354 & $0.691^{*}$ & 0.480 & $0.894^{* *}$ & 1 & & \\
\hline 11 Chromium (mg/l) & -0.338 & 0.279 & -0.377 & -0.389 & 0.034 & -0.424 & 0.072 & $0.837^{* *}$ & $0.833^{* *}$ & 0.635 & 1 & \\
\hline 12 Cadmium (mg/l) & -0.130 & $0.826^{* *}$ & -0.226 & -0.394 & 0.284 & 0.450 & 0.560 & 0.588 & $0.854^{* *}$ & $0.951^{* *}$ & 0.594 & 1 \\
\hline
\end{tabular}

*. Correlation is significant at the 0.05 level (2-tailed).

**. Correlation is significant at the 0.01 level (2-tailed).

Table 5: Pearson's correlation coefficient ( $\mathrm{r}$ ) between water heavy metal parameters with benthic macro-invertebrates abundance of Erelu Reservoir. 


\section{Journal of Ecology and Natural Resources}

\begin{tabular}{|l|c|c|c|c|c|c|c|c|c|}
\hline \multicolumn{1}{|c|}{ Parameters } & $\mathbf{1}$ & $\mathbf{2}$ & $\mathbf{3}$ & $\mathbf{4}$ & $\mathbf{5}$ & $\mathbf{6}$ & $\mathbf{7}$ & $\mathbf{8}$ & $\mathbf{9}$ \\
\hline 1. Diptera & 1 & & & & & & & & \\
\hline 2. Coleoptera & -0.222 & 1 & & & & & & & \\
\hline 3. Hemiptera & 0.533 & 0.310 & 1 & & & & & & \\
\hline 4. Odonata & 0.490 & -0.155 & 0.555 & 1 & & & & & \\
\hline 5. Lead (mg/kg) & 0.556 & -0.303 & 0.092 & -0.026 & 1 & & & & \\
\hline 6. Iron (mg/kg) & 0.168 & -0.158 & -0.176 & 0.525 & 0.102 & 1 & & & \\
\hline 7. Zinc (mg/kg) & 0.620 & -0.472 & 0.061 & 0.208 & $0.905^{* *}$ & 0.426 & 1 & & \\
\hline 8. Chromium (mg/kg) & -0.064 & -0.150 & -0.313 & 0.305 & -0.227 & $0.837^{* *}$ & 0.151 & 1 & \\
\hline 9. Cadmium (mg/kg) & -0.130 & 0.032 & -0.316 & 0.400 & -0.208 & $0.912^{* *}$ & 0.065 & $0.839^{* *}$ & 1 \\
\hline
\end{tabular}

*. Correlation is significant at the 0.05 level (2-tailed).

**. Correlation is significant at the 0.01 level (2-tailed).

Table 6: Pearson's correlation coefficient $(r)$ between sediment heavy metal parameters with insect macro-invertebrates abundance of Erelu Reservoir.

\begin{tabular}{|l|c|c|c|c|c|c|c|c|c|c|c|c|}
\hline \multicolumn{1}{|c|}{ Parameters } & $\mathbf{1}$ & $\mathbf{2}$ & $\mathbf{3}$ & $\mathbf{4}$ & $\mathbf{5}$ & $\mathbf{6}$ & $\mathbf{7}$ & $\mathbf{8}$ & $\mathbf{9}$ & $\mathbf{1 0}$ & $\mathbf{1 1}$ & $\mathbf{1 2}$ \\
\hline 1. Architaenioglossa & 1 & & & & & & & & & & & \\
\hline 2. Capitellida & 0.056 & 1 & & & & & & & & & & \\
\hline 3. Diptera & 0.083 & -0.295 & 1 & & & & & & & & & \\
\hline 4. Hygrophila & 0.637 & -0.132 & 0.005 & 1 & & & & & & & & \\
\hline 5. Pulmonata & 0.211 & -0.134 & 0.322 & 0.045 & 1 & & & & & & & \\
\hline 6. Sorbeoconcha & 0.324 & 0.590 & 0.283 & 0.050 & 0.315 & 1 & & & & & & \\
\hline 7. Unionidae & 0.191 & 0.244 & 0.464 & -0.272 & $0.808^{* *}$ & 0.588 & 1 & & & & & \\
\hline 8. Lead (mg/kg) & 0.516 & -0.110 & 0.505 & $0.683^{*}$ & -0.078 & 0.389 & -0.112 & 1 & & & & \\
\hline 9. Iron (mg/kg) & 0.050 & $0.691^{*}$ & 0.282 & -0.041 & 0.425 & $0.692^{*}$ & 0.645 & 0.102 & 1 & & & \\
\hline 10 Zinc (mg/kg) & 0.468 & -0.035 & $0.680^{*}$ & 0.605 & 0.230 & 0.499 & 0.199 & $0.905^{* *}$ & 0.426 & 1 & & \\
\hline 11 Chromium (mg/kg) & 0.099 & 0.457 & 0.202 & -0.173 & $0.779^{*}$ & 0.531 & $0.878^{* *}$ & -0.227 & $0.837^{* *}$ & 0.151 & 1 & \\
\hline 12 Cadmium (mg/kg) & -0.003 & $0.854^{* *}$ & -0.057 & -0.220 & 0.346 & 0.649 & 0.616 & -0.208 & $0.912^{* *}$ & 0.065 & $0.839^{* *}$ & 1 \\
\hline
\end{tabular}

*. Correlation is significant at the 0.05 level (2-tailed).

**. Correlation is significant at the 0.01 level (2-tailed).

Table 7: Pearson's correlation coefficient (r) between sediment heavy metals parameters with benthic macro-invertebrates abundance of Erelu Reservoir.

T-test of significance showing variations of heavy metals in water samples of the three stations are presented in table 1 . The result showed that Lead $(\mathrm{mg} / \mathrm{L})$ varied insignificantly $(p>0.05)$ between seasons and across the stations. Iron, Zinc and Chromium were significant $(p<0.01)$, while Cadmium significantly differ only in the inlet and outlet stations. Pearson's correlation coefficient revealed Lead to have inverse relationship with Diptera $(r=-0.185)$ and Coleoptera $(\mathrm{r}=-0.070)$ but a significant correlation with Odonata $\left(0.743^{*}\right)$. Iron related with Lead $\left(r=0.755^{*}\right)$ significantly. Chromium has a strong significant $(p<0.01)$ association with lead $\left(\mathrm{r}=0.837^{* *}\right)$ and Iron $\left(\mathrm{r}=0.833^{* *}\right)$, while Cadmium had a strong significant $(p<0.01)$ correlation with Zinc $\left(\mathrm{r}=0.951^{* *}\right)$ and Iron $\left(\mathrm{r}=0.854^{* *}\right)$ respectively (Table 3$)$. Iron related with Lead $\left(\mathrm{r}=0.755^{*}\right)$. Zinc showed positive association with Unionidea ( $\left.\mathrm{r}=0.691^{*}\right)$ and Iron $\left(\mathrm{r}=0.894^{* *}\right)$ while Cadmium has a closed association with Capitellida $\left(\mathrm{r}=0.826^{* *}\right)$ respectively (Table 4). The Lead and Zinc $\mathrm{mg} /$ $\mathrm{kg}$ in sediment samples were significant $(p<0.01)$ between seasons and across sampling stations. Iron $\mathrm{mg} / \mathrm{kg}$ revealed non-significant $(p>0.05)$ across seasons and stations, while Chromium and Cadmium $\mathrm{mg} / \mathrm{kg}$ were significant only at inlet and reservoir stations respectively. Zinc $\mathrm{mg} / \mathrm{kg}$ related significantly with Lead $\left(r=0.905^{* *}\right)$. There was a 


\section{Journal of Ecology and Natural Resources}

close association between Chromium and Iron ( $\mathrm{r}=0.837^{* *}$ ), Cadmium and Iron ( $\left.r=0.912^{* *}\right)$. Heavy metal parameters were either positively and inversely related with insect orders (Table 5). The benthic order Unionidea related with Pulmonata $\left(\mathrm{r}=0.808^{* *}\right)$ strongly while Lead had correlation with Hygrophila $\left(r=0.683^{*}\right)$. Iron closely associated with Capitellida ( $\left.\mathrm{r}=691^{*}\right)$ and order Sorbeoconcha ( $\mathrm{r}=$ $0.692^{*}$ ) respectively. Zinc $\mathrm{mg} / \mathrm{kg}$ in sediment samples had correlation with Diptera ( $\left.\mathrm{r}=0.680^{*}\right)$, while Chromium mg/kg related strongly with Pulmonata $\left(\mathrm{r}=0.779^{*}\right)$; Unionidea $(\mathrm{r}=$ $0.878^{* *}$ ) and Iron ( $\left.\mathrm{r}=0.837^{* *}\right)$ respectively. Cadmium mg/ $\mathrm{kg}$ revealed significant $(p<0.01)$ relationship with Capitellida $\left(\mathrm{r}=0.854^{* *}\right)$; Iron ( $\left.\mathrm{r}=0.912^{* *}\right)$ and Chromium $\left(\mathrm{r}=0.839^{* *}\right)$ respectively.

\section{Discussion}

The non-significant spatial and seasonal variation of the $\mathrm{Pb}$ in water samples of Erelu reservoir could be due to similar source of input into the water body. Similar observation was reported by Taiwo and Adebukola $[15,16]$ in Opa Reservoir. The significant seasonal variation of Fe, $\mathrm{Zn}$ and $\mathrm{Cr}(\mathrm{mg} / \mathrm{L})$ could be due to waste input or influx of flood during rainy season that might bring the the content of the metal. Identical report was observed by Kimani, et al. [17] in Chania River Kenya and Iqra Azam, et al. [18] in Pakistan who related to urban expansion, tanneries that enhanced pollution threat the studied river. The strong association of $\mathrm{Pb}$ with Odonata indicated positive impact on its abundance. Similar observation was made by Girgin, et al. [19] where Cd, $\mathrm{Pb}, \mathrm{Cu}, \mathrm{Zn}$ and $\mathrm{Fe}$ were reported to have relationship with insect community of the study area. Contrary report was observed by Fredrick 0 [20]. Relationship between heavy metals like $\mathrm{Fe}, \mathrm{Cd}$, with $\mathrm{Pb}$ and $\mathrm{Cr}$ in water samples could be associated with similar source into the reservoir. This observation disagrees with the report of Hong-Yan, et al. [21] who also reported significant variation of metals of the two Chinese Rivers. The abundance of Diptera, Coleoptera, Hemiptera, Architaenioglossa, Capitellida and Hygrophila which are independent of the heavy metals in water samples indicated no effects on their abundance. This report is in line with the observation of Fouzia I, Ayoade AA [22,23] who also reported negative association of some metals with the abundance of class Insecta. The $\mathrm{Zn}$ and $\mathrm{Cd}$ that strongly related to Unionidea and Capitellida could be ascribed to their impact on the benthic orders. The significant variation of $\mathrm{Pb}$ in sediment samples across year and stations indicated varied sources into the river during wet and dry season. Similar observation was reported by Kimani, et al. [17] in Kenya. The $\mathrm{Cr}$ and $\mathrm{Cd} \mathrm{mg/kg}$ that were significant only in the inlet and reservoir stations could be attributed to fertilizer input from agricultural field in the inlet and runoff into the reservoir. This report is in accordance with the observation of Sahadat, et al. [24] who reported insignificant variation of $\mathrm{Cd}, \mathrm{Cr}, \mathrm{Zn}, \mathrm{Pb}$ and $\mathrm{Ni}$ across stations in their study area. The strong significant association of heavy metals such as $\mathrm{Cr}$ and Iron, $\mathrm{Cd}$ and Iron in sediment samples may be attributed to their bioaccumulation in the reservoir sediment. The Unionidea and Pulmonata that had close correlation may be due to their abundance in fairly polluted environment. Lead in the sediment samples that showed positive significant correlation with hygrophila (Lymnae natalensis) has influence on its abundance but showed no relationship with other groups of benthic macro-invertebrates. This implies that lead has impacts on Lymnae species abundance. Iron in the sediment samples positive correlation within Capitellida and Sorbeoconcha implied that iron determines their abundance. The positive significant relationship between Zinc, Lead and Dipteran indicated similar source of pollution in the reservoir and great tolerance of Dipteran in a contaminated environment as Zinc influenced its abundance [25]. Negative correlation of Zinc with Hemiptera was observed by Girgin, et al. [19]. The positive significant correlation between Chromium with Pulmonata, Unionidea and Iron may be due to contamination of water by human wastes. Okoro [26] reported Iron to be correlated with coleopteran. Chromium, Iron and Lead, were also significantly related, which might have similar source of input into the reservoir Ewa, et al. [27]. The positive significant correlation between cadmium in the sediment samples with Capitellida, Iron and Chromium showed relationship with the Capitellida since it is a worm that dwells directly in the sediment and oxygen depleting environment.

\section{Conclusion}

It was concluded that there were seasonal variations of metal across stations which implied that sources of metal during raining season is different from that of drying season and that reduced level of water has implication on the concentration of metal during dry season. The significant relationship of some heavy metals on the abundance of macro-invertebrates indicated that their influence on them, while some heavy metals showed inverse relationship with macro-invertebrates which implies their decrease concentrations caused rise in the abundance of the organisms. Some metals related inversely, an indication of varied sources into the reservoir. Heavy metals have no much influence on the aquatic insects compared to the benthic macro-invertebrates, particularly the sediment heavy metals of Erelu Reservoir. This is because the benthos inhabit in the sediment and directly feel the impact of metal pollution. However, abundance of macro-invertebrates could be traced to other factors such as substrate richness, favourable DO, $\mathrm{pH}$, temperature and clarity of water body. Therefore, heavy metals in the sediment samples of Erelu reservoir has more impact on the abundance of macro-invertebrates compared to that of water samples. 


\section{Journal of Ecology and Natural Resources}

\section{References}

1. Ali H, Khan E (2018) What are Heavy Metals? Longstanding controversy over the scientific use of the term heavy metal's proposal of a comprehensive definition. Toxicological Environmental Chemistry 100(1): 6-19.

2. Appenroth KJ (2010) What are Heavy Metals in Plant Sciences?. Acta Physiologiae Plantarum 32(4): 615-619.

3. Kennish JR (1992) Ecology of Estuaries: Anthropogenic Effects. CRC Press, Inc. Boca Raton, pp: 74.

4. Chapman D Hall (1992) Water Quality Assessment: a guide to the use of biota, sediments and water in environmental monitoring London, pp: 1-11.

5. Valavanidis A, Thomas T (2010) Agricultural pesticides: ecotoxicological studies and Environmental Risks Assessment. Sci Adv Environ Toxicol Ecotoxicol Issues pp: 1-15.

6. Barwick M, Maher W (2003) Biotransference and Biomagnification of Selenium, Zinc, Arsenic and Lead in a Temperate Seagrass Ecosystem from Lake Macquarie Estuary, NSW, Australia. Marine Environmental Research 56(4): 471-502.

7. Ufoegbune GC, Oparinde OC, Eruola AO (2011) Municipal Water supply planning in Oyo metropolis, Oyo State, South-western Nigeria. Journal of Geography and Regional Planning 4(7): 392-400.

8. Akintola FO, Adeniyi G (1997) Land-use changes and water quality in impounded water supply dams in Southwest Nigeria. Freshwater contamination. Proceeding of Rabat symposium $\mathrm{S}_{4}$ AHS publ 243: 313319.

9. Association of Analytical Chemist (2000) Official Methods of Analysis of the Association of Official Analytical Chemist, $17^{\text {th }}$ (Edn.), Arington, Virginia, USA, pp: 200.

10. Phyllis MM, Miles HB, Graham VE (1970) Tropical Freshwater. Ecology, pp: 1-33.

11. Pennak RW (1978) Freshwater invertebrates of the United States, $2^{\text {nd }}$ (Edn.), John Wiley and Sons, New York, pp: 810 .

12. Merritt RW, Cummins KW (1996) An introduction to the Aquatic Insects of North America, $3^{\text {rd }}$ (Edn.), Dubuque, Kendall-Hunt, IOWA, pp: 862.

13. John M (2012) Extramadura keys to the identification of Dragonflies and Damselflies (Odonata) pp 1-3.
14. Needham JG, Westfall MJ, May ML (2000) Dragonflies of North America.Revised edition. Scientific Publishers, Inc., Gainesville, FL, pp: 940.

15. Taiwo A, Adebukola, AA (2016) Temporal and Spatial fluctuations of Heavy Metals in Opa Reservoir, Ile-Ife, Nigeria. African Journal of Aquatic Science 41(4): 435443.

16. Andriaan Du plessis (2015) Assessment of Heavy metal concentrations in water and sediment of Dams in central Namibia and bioaccumulation of Copper in locally occurring Crabs and Fish. MSc Project, Department of Biological Science, University of Namibia. pp: 55-74.

17. Kimani PK, Thiongo GT, Nwangi JK (2016) Spatial and Seasonal Variation of selected water Quality parameters in Chania River Catchment, Kenya. British Journal of Applied Science and Technology 18(3): 1-6.

18. Iqra Azam, Sumera Afsheen, Ahmed Zia, Muqaddas Javed, Rashid Saeed, et al. (2015) Evaluating Insects as Bioindicators of Heavy Metal Contamination and Accumulation near Industrial Area of Gujrat, Pakistan. Biomed Research International pp: 942751.

19. Girgin S, Nkzanc, Dugel MC (2010) Relationship between Aquatic insects and heavy metals in an urban stream, Turkey, using multivariate techniques. International Journal Environmental Sciences Technology 7(4): 653664.

20. Fredrick O, Hudson L (2016) Macro-invertebrarates As Bioindicator of water Quality stream in Mbeya, Tanzania. International Journal Scientific Technology Research 5(6): 211-222.

21. Hong Yan, Xin Qian, Hailong Gao, Yulei wang, Bisheng Xia (2014) Seasonal and Spatial variations of Heavy Metals in two typical Chinese Rivers: Concentrations Environmental Risks and Possible sources. International Journal Environ Res Public Health 11(11): 11860-11876.

22. Fouzia I, Amir K (2014) Seasonal Limnological Variation and Macro-benthic Diversity of River Yamuna at Kalsi Dehradun of Uttarakhand. Asian Journal of Plant Science and Research 3(2): 133-144.

23. Ayoade AA, Olusegun AO (2012) Impacts of Effluents on the limnology of a Tropical Rivers Southwestern Nigeria. J Appl Sci Environ Manage 16(2): 201-207.

24. Shahadat MH, Nani GD, Subrata S, Ziaur MR (2012) Fish Diversity and habitat relationship with environmental variables at Meghna river estuary, Bangladesh. The Egyptian Journal Aquatic Res 38(3): 213-226. 
Journal of Ecology and Natural Resources

25. Deliz-Quinone KY (2005) Water quality assessment of a tropical fresh waters marsh using Aquatic insects. MSc. Thesis, Department of Biology, University of Puerto Rico, pp: 148.

26. Okoro OJ (2015) Ecology of Aquatic insects in Opi Lake, Enugu .Nigeria. An M.Sc. Project. Dept. of Zoology and
Environmental Biology. Faculty of Biological Sciences, University of Nigeria Nsukka, pp: 84-93.

27. Ewa EE, Iwara AI, Offiong VE, Essoka PA, Njar GN (2013) Seasonal variations in Heavy metal status of the Calabar River, Cross river State, Nigeria. J Natural Sci Res 3(11): 78-84. 